\section{Editors}

Mario Carretero

Campus de Cantoblanco

Autónoma University of Madrid

Madrid, Spain and Latin American

Faculty of Social Sciences FLACSO,

Argentina

\author{
Stefan Berger \\ Ruhr Universitat Bochum \\ Bochum, Germany
}

\author{
Maria Grever \\ Erasmus School of History, \\ Culture and Communication \\ Erasmus University Rotterdam, \\ Rotterdam, The Netherlands
}

ISBN 978-1-137-52907-7 ISBN 978-1-137-52908-4 (eBook)
DOI 10.1057/978-1-137-52908-4

Library of Congress Control Number: 2016958284

(C) The Editor(s) (if applicable) and The Author(s) 2017

The author(s) has/have asserted their right(s) to be identified as the author(s) of this work in accordance with the Copyright, Designs and Patents Act 1988.

This work is subject to copyright. All rights are solely and exclusively licensed by the Publisher, whether the whole or part of the material is concerned, specifically the rights of translation, reprinting, reuse of illustrations, recitation, broadcasting, reproduction on microfilms or in any other physical way, and transmission or information storage and retrieval, electronic adaptation, computer software, or by similar or dissimilar methodology now known or hereafter developed.

The use of general descriptive names, registered names, trademarks, service marks, etc. in this publication does not imply, even in the absence of a specific statement, that such names are exempt from the relevant protective laws and regulations and therefore free for general use.

The publisher, the authors and the editors are safe to assume that the advice and information in this book are believed to be true and accurate at the date of publication. Neither the publisher nor the authors or the editors give a warranty, express or implied, with respect to the material contained herein or for any errors or omissions that may have been made. The publisher remains neutral with regard to jurisdictional claims in published maps and institutional affiliations.

Cover illustration: JOHN KELLERMAN / Alamy Stock Photo

Printed on acid-free paper

This Palgrave Macmillan imprint is published by Springer Nature

The registered company is Macmillan Publishers Ltd.

The registered company address is: The Campus, 4 Crinan Street, London, Nl 9XW,

United Kingdom 


\section{Contents}

1 Introduction: Historical Cultures and Education in Transition I Mario Carretero, Stefan Berger, and Maria Grever

Part I Historical Culture: Conceptualizing the Public Uses of History

2 History Writing and Constructions of National Space: The Long Dominance of the National in Modern European Historiographies

Stefan Berger

3 Historical Consciousness and Historical Thinking Peter Seixas

4 Historical Culture: A Concept Revisited Maria Grever and Robbert-Jan Adriaansen

5 Historical Rights to Land: How Latin American States Made the Past Normative and What Happened to History and Historical Education as a Result Tamar Herzog

6 'The Times They Are a-Changin'. On Time, Space and Periodization in History

Chris Lorenz 
7 Democracy and History Museums. Museo de América

Marisa González de Oleaga

8 Illustrating National History

Peter Burke

9 Film, the Past, and a Didactic Dead End:

From Teaching History to Teaching Memory

Wulf Kansteiner

10 Historical Edutainment: New Forms and Practices of Popular History?

Barbara Korte and Sylvia Paletschek

11 The Jurassic Park of Historical Culture

Antonis Liakos and Mitsos Bilalis

Part II The Appeal of the Nation in History

Education of Postcolonial Societies

12 Teaching National History to Young People Today Jocelyn Létourneau

13 Echoing National Narratives in English History Textbooks Tina Van der Vlies

14 Colonial and Postcolonial Contexts of History Textbooks Susanne Grindel

15 History in French Secondary School: A Tale of Progress and Universalism or a Narrative of Present Society?

Nicole Tutiaux-Guillon

16 National Narratives and the Invention of Ethnic Identities: Revisiting Cultural Memory and the Decolonized State in Morocco

Norah Karrouche 
26 Social Representations of the Past and Competences in History Education

Darío Páez, Magdalena Bobowik, and James Liu

27 Teaching History Master Narratives: Fostering Imagi-Nations Mario Carretero

28 Organizing the Past: Historical Accounts, Significance and Unknown Ontologies

Lis Cercadillo, Arthur Chapman, and Peter Lee

29 Historical Reading and Writing in Secondary School Classrooms

Jeffery D. Nokes

30 Engaging Students in Historical Reasoning: The Need for Dialogic History Education

Carla van Boxtel and Jannet van Drie

Part IV Educational Resources: Trends in Curricula, Textbooks, Museums and New Media

31 Bridging the Gap. Comparing History Curricula in History Teacher Education in Western Countries Nicola Brauch

32 Cultural Wars and History Textbooks in Democratic Societies Tony Taylor and Stuart Macintyre

33 Trends and Issues Surrounding the Reading of Historical Texts in the Republic of Korea Ho Hwan Yang

34 History Education Reform in Twenty-First Century China Side Wang, Yueqin Li, Chencheng Shen, and Zhongjie Meng

35 Tools in Teaching Recent Past Conflicts: Constructing Textbooks Beyond National Borders 
36 Emotional, Moral, and Symbolic Imagery of Modern History Textbooks

Tatyana Tsyrlina-Spady and Michael Lovorn

37 Educational Websites on the Memory of Slavery in Europe: The Ongoing Challenge of History Teaching Stephan Klein

38 Social Media, New Technologies and History Education Terry Haydn and Kees Ribbens

39 The Never-ending Story About Heritage and Museums: Four Discursive Models

Mikel Asensio and Elena Pol

Name Index 


\title{
Film, the Past, and a Didactic Dead End: From Teaching History to Teaching Memory
}

\author{
Wulf Kansteiner
}

\section{Two Golden Girls and a Divorce}

In 1992, one of the flagship publications of professional historiography, the American Historical Review (AHR), changed its editorial profile. Henceforth some issues of the journal would contain reviews of historical films and help historians come to terms with a medium that was about to celebrate its hundredth anniversary (Rosenstone, 1992). Clearly, the decision to initiate an ongoing dialogue about cinematographic ways of representing the past in the exalted pages of the $A H R$ was taken with considerable delay. In fact, in 1992, the $A H R$ was also almost 100 years of age. So here was one centenarian reaching out to another centenarian in an effort to improve a relationship that, as far as professional historiography was concerned, had been dominated by feelings of arrogant indifference, elitist distrust, and audience envy. For the longest time, most historians considered cinema a social institution involved in the moral corruption of the masses and the systematic falsification of the historical record (Chapman, 2013: 74; Smyth, 2012: xvii). The slow, begrudging acknowledgment of movies as a force to be reckoned with in the business of representing the past was primarily triggered by the recognition that audiences, including elite audiences, did not share the historians' reservation about the medium and happily and actively developed their historical identities through the consumption of film and television (Grainge, 2003; Monk, 2011). That realization did not prompt many historians to turn to film as a new distribution system for their stories about the past, far from it. But they gradually acknowledged the relevance of film as a cultural force in its own right and concluded that the writing of contemporary history required a better understanding of film as a tool of

W. Kansteiner $(\bowtie)$

Department of History, Aarhus University, Jens Chr. Skous Vej 5, Aarhus, 8000 C, Denmark 
mass communication and that the analysis of the history of collective memory required a better understanding of the visions of the past propagated by film. Put differently, historians tried to get a handle on twentieth century visual culture by reducing film to the status of a historical source (e.g. O'Connor, 1987; Short, 1981). That approach produced excellent social and cultural histories but also re-establish a much-cherished hierarchical differentiation between professional and allegedly amateurish attempts of representing the past (e.g. Ross, 1999). Occasionally, historians have themselves become involved in the production of historical films but largely without having been able to transform specifically historiographical interpretations of the past into popular film fare (Burnett, 2008; Stubbs, 2014).

In 1992, the AHR editorial board could not have selected a more suitable editor for the job of establishing diplomatic relations to film. With Robert Rosenstone, they picked a well-known pioneer of historical film studies, who had made a compelling case for considering film a valuable and independent cultural arena of historical reflection that had to be assessed according to its own, as yet to be precisely determined rules of plausibility. In path-breaking publications, Rosenstone sought to understand the construction principles of historical film from a filmmaker's point of view starting from the fundamental assumption that mainstream cinema, fiction as well as non-fiction, "emotionalizes, personalizes, and dramatizes history" (Rosenstone, 1995a: 59; see also Rosenstone, 2006). Consequently, film narratives focus on famous or exceptional individuals, self-confidently depict the past as a closed narrative universe, and take on the form of a Gesamtkunstwerk that in the act of mimetic depiction combines different historical themes and genres such as economic, politi$\mathrm{cal}$, or gender history in one grand, integrated vision of the past. Mainstream film simulates rather than analyzes history and, by fixing the look and feel of things past on celluloid, leaves no opportunities for doubt and uncertainty. Mainstream film gives us "history as triumph, anguish, joy, despair, adventure, suffering, and heroism" (Rosenstone, 1995a: 59) and is fundamentally optimistic: "no matter what the historical film, be the subject matter slavery, the Holocaust, or the Khmer Rouge, the message delivered on the screen is almost always that things are getting better" (56). From Rosenstone's poststructuralist vantage point, mainstream historical film and mainstream historiography share key characteristics, including their ideological commitments to narrative reconstruction and myths of historical authenticity. But film, with its exuberant optimism and its direct access to people's senses and emotions, excels at the job of covering its tracks and depicting its highly selective vision of the past as inevitable truth. No wonder then that historians regard film with a great deal of suspicion. As private individuals they often enjoy historical film as much as the next person, and perhaps even more so. But in their role as professional historians, they decry the unwanted competitor's sustained success in shaping and reflecting people's historical imagination which historians would like to influence according to their own narrative and analytical predilections (Schwarz, 2008: 205). 
The AHR project failed. In 2006, the journal filed for divorce and canceled its historical film section because the reviews had yielded increasingly predictable and redundant results (Hughes-Warrington, 2009; Schneider, 2006). Time and again, the majority of historians chosen to explain historical films to their colleagues quibbled over inconsequential factual mistakes in film productions and failed to clarify let alone appreciate the specific accomplishments of filmic visions of history. In contrast, a minority faction of reviewers used the pages of the AHR to celebrate the extraordinary self-reflexivity of auteur history films. They embraced the legacies of the New German Cinema and the French New Wave cherishing a visual language capable of deconstructing the myth that films or any other media amount to an objective reflection of past reality (Rosenstone, 1995a: 201; see also the contributions to Rosenstone, 1995b). In the end, Rosenstone could not help solve a dilemma he had already grasped a decade earlier. The few historians who are genuinely intrigued by filmic visions of history and who often also entertain rather self-critical, poststructuralist inflected notions about the historical profession are inexorably drawn to experimental cinema which exudes aesthetic, political, and epistemological self-reflexivity but has no mass appeal. In contrast, their more numerous empirically inclined "dragnet" colleagues never developed much of an appreciation of visual historical discourse. As a result, there are hardly any advocates in professional academic historiography for big budget, Hollywood-style films and mainstream TV productions which shape the historical imaginations of millions of viewers on a daily basis. For many historians, professional history and public visual memory remain antagonistic realms of historical consciousness. Consequently, the questions of what objectives can be pursued by teaching about the past through visual media and how these objectives can be obtained responsibly requires an interdisciplinary vantage point that pays a great deal of attention to the concerns of academic historians but also looks elsewhere for inspiration for instance in the fields of public history, memory studies, media studies, cinema studies, history didactics, and pedagogy (Guynn, 2006).

\section{Film and the Historical Profession}

The high profile AHR excursion and withdrawal from the terrain of historical film is emblematic for a long and difficult relationship between the historical profession and film that has had grave consequences for the teaching of history through visual media. Siegfried Kracauer, one of the first intellectuals to explore in depth the relationship between cinema and history in the 1940s and 1950s, emphasized the structural similarities between cinematographic and academic strategies of appropriating the past. In his view, the two historical cultures offer similarly unstable and similarly attractive semantic hybrids. Filmmakers and historians seek to render a faithful representation of past events and, at the same time, integrate these events into purposeful narrative trajectories that make a great deal of sense to their respective audiences. They partake in the auras of truth and beauty (Kracauer, 1969). 
In principle, the structural affinities could have given rise to intellectual companionship and collaboration but filmmakers and historians have developed different self-images and therefore often traveled at cross-purposes. Historians narrate to tell the truth while filmmakers capture reality to craft good stories. The combination of structural proximity and diverging public personae and intellectual objectives has caused a great deal of confusion and distrust (Guynn, 2006; Treacey, 2016). For most of the twentieth century, historians interested in film entertained the notion that non-fiction film might perhaps play a useful role as a historical source and therefore deserves to be archived (Ramirez, 2014: 8-9). But for the very same minority of historical film supporters feature films were simply anathema in history teaching because they combined audience appeal with gruesome misrepresentations of history and thus constituted a serious moral risk for modern societies. Historians have therefore spent considerable time correcting the mistakes of cinema history (e.g. Carnes, 1996; Custen, 1992). Consider as a case in point Charles Beard's infamous indictment of the Academy Award winning movie The Private Life of Henry VIII released in 1933 (Beard, 1934). In an intervention that film scholar James Chapman calls "absurdly pedantic," Beard, a scholar and public intellectual of exceptional stature, thus joined the ranks of the many uniformbutton-counters in the historical profession (Chapman, 2013: 75). The situation did not improve after World War II because film was now charged with having played a decisive role in bringing to power, and keeping in power, fascist and communist dictators of all sorts. As late as 1970, the German history didactic expert Harald Witthöft wondered if it could be justified to exhibit in the classroom the carefully edited documentaries about NS history compiled by the West German Göttingen Institute for Scholarly Film. He reflected the opinion of the majority of his peers when he contemplated the "seduction factor" attributable to NS visual documents against which contemporary West German youth might not have acquired sufficient "immunity" (Witthöft, 1970: 218). With these kinds of friends historical film did not need any of its plentiful enemies in academia.

The situation slowly changed in the context of the social movement of the 1960s and 1970s when the theme of film and history developed into a bona fide academic subfield with its own conferences, professional associations, and publication venues. Important landmarks in this context include the launch of the journal Film and History in 1970, the publication of the influential edited volume The Historian and Film in 1976, and the founding of the Historical Journal of Film, Radio and Television in 1981 (Smith, 1976). The process of institutionalization was decisively influenced by the rapid dissemination and popular appreciation of television which gave rise to non-fiction, World War II-related media events like the The World at War (1973) and Das Dritte Reich (1970). Moreover, even historical fiction film found now vigorous academic advocates. In particular the French sociologist Pierre Sorlin and the French historian Marc Ferro argued compellingly that movies both reflect and shape contemporary ideologies and thought styles. Confirming the key insights 
of the linguistic turn in the humanities, Sorlin maintained that all films, fiction and non-fiction alike, are overwhelmingly made up of fictional elements because they "reconstruct in a purely imaginary way the greater part of what they show" (Sorlin, 1980: 27). For Sorlin, both the deictic and the narrative function of film carry the unequivocal imprints of a given film's historical context. Consequently, as Ferro argues, it makes little sense to differentiate between historical and non-historical feature films. He prefers to classify movies according to their social and political function as either affirmative or critical cultural agents - recognizing full well that truly critical films are a relatively rare phenomenon (Ferro, 1988). In the end, however, the intellectual relevance of the turning point of the 1970s should not be exaggerated. The fact that film and history became an independent research field primarily reflects the expansion and differentiation of professional historiography since the 1960s; it does not mark a decisive change in attitude of the profession as whole with regard to the representation of history in visual media, as above $A H R$ episode illustrates.

\section{Historians, Film, and Classroom Didactics}

The suspicion and the sense of helplessness with which historians reacted to visual culture in their roles as professional interpreters of the past has had serious consequences for the use of film and television in the classroom. Deepseated fears persisted even after history of film and TV had been established as a respectable subfield within the historical profession in Europe and the USA. In fact, even the minority faction of historians actively advocating for the use of film and television in classroom teaching felt compelled to begin their didactic suggestions with stark words of warning about the dangerous medium film. In this vein, John O'Connor, in the quasi-official 1987 AHA guide Teaching History with Film and Television, warned high school teachers three times on the first page of his intervention that they "should integrate more critical film and television analysis in their history classes," "should perhaps use less film and video, but analyze what they do use more critically," and encourage students "to engage, rather than suspend, their critical faculties when the projector or the TV monitor is turned on" (O'Connor, 1987: 1; emphasis added by author, see also Burnett, 2008). The mantra-like invocation of the critical faculties of historiography in defense against the dark arts of film and TV provides little information about visual media and a great deal of insight into the self-definition of historians. They, unlike the visual media, can teach students "skills of critical evaluation" suited for "an open and democratic society" and "a free marketplace of ideas;" they, unlike the visual media, have acquired an aptitude "for subtle shadings of interpretation;" they, unlike the visual media, do not mislead and manipulate students; and they, unlike the visual media, are "more than a storyteller, stringing together dates and details and arbitrarily moving characters around" (O'Connor, 1987: 3-4). But O'Connor would not be an expert for film and television history if he did not have an inkling about film's special gift for helping students "feel" and 
"re-experience the past" by transporting them "across space and time so that distant events and far-flung parts of the world seem more real and relevant" (O'Connor, 1987: 1-2). Therefore, he calls upon the wizard-teachers in the classrooms who can tame the beast because "when carefully integrated into the course, and when properly handled by the sensitive teacher, lessons based on film and television analysis can improve the effectiveness of history teaching" (O'Connor, 1987: 2). In the end, O'Connor is disarmingly honest about the anxieties fueling his defensive shadow-boxing against visual history. He is afraid that the "steady diet of television docudramas and pseudo-docudramas, from Plymouth Plantation to Roots and Watergate, from I Claudius to Shogun and the Winds of War, has begun to undermine whatever respect there might have been in the public mind for the work of the professional historian and history teacher" (O’Connor, 1987: 3).

There is no indication that historians have ever played the role O'Connor attributes to them-or historians have at least always managed to hide effectively the natural affinity between democratic values and professional historiographic practices and, with few exceptions, served their nationalistic, fascist, Communist, and neo-capitalist overlords with varying degrees of enthusiasm. Nor is there any indication that visual culture in general, and film or TV producers in particular, are more likely to support non-democratic regimes than other art forms and social elites, as O'Connor indirectly alleges. Finally, notice in this context the absence of the 1978 TV-miniseries Holocaust from O'Connor's list of indicted docudramas. Apparently, it was inopportune to highlight in 1987 the factual shortcomings and manipulative design of Holocaust in light of the TV series' extraordinary ability to raise awareness of the plight of the victims of the Shoah and the media event's less frequently noted side effect of highlighting how little research about the history of the "Final Solution" historians had accomplished in four post-war decades (Shandler, 1999: 155-178). Precisely because of these unreflected assessments O'Connor's intervention deserves close attention; he develops an intriguing symbolic landscape in which the visual media's seductive capacity for simulation is contrasted with the trustworthy, objective sobriety of academic scholarship. In O'Connor's distopia, the visual media draw their consumers in, unmoor them from their safe grounding in time and space, and deliver them to a fictitious world in a process of mimetic approximation that is both exciting and dangerous. O'Connor and his many predecessors appear to perceive a real risk that the morally weak and intellectually unprepared, especially children and adolescents identify with attractive yet faulty renditions of history and that this identification, forged in a maelstrom of attractive visuality, has dire lasting consequences for society. The historiographically witless viewers get stuck in the wrong past. Hence O'Connor wants to subject the consumption of visual history to the professional restraints of historical scholarship hoping that experts remain in control of subject matter and audiences. At the same time, O'Connor's consistently defensive intervention attests to the realization, shared across the discipline, that the war is lost. Historians have simply nothing they can throw into battle 
that would be a match for the modern seductress film. In contrast to film, history books cannot be blamed for overwhelming the emotional defenses of their readers, but they carry the very real danger, especially the specimen designed for classroom use, of inducing feelings of utter boredom and genuine indifference in captive audiences familiar with the sensuality of film history. As a result, the theory of history didactics as designed by historians and the practice of history didactics as pursued by teachers have diverged substantially. Film is omnipresent in the history classroom for purposes of historical entertainment and simulation not historiographical disciplining (Marcus \& Levine, 2007). The discrepancy is likely to induce feelings of unease in everybody familiar with historians' anti-film prejudice, including some teachers. There is something salacious about the presence of film in the history classroom.

The historians' reservations about film and television are hardly an unusual phenomenon in the context of modern media history. These kinds of misgivings develop in many dynamic media environments when historically older and historically younger media formats and paradigms interact and compete. Very similar reservations are currently entertained about digital interactive culture. In particular video games are often considered an engrossing and potentially dangerous media format alleged to produce generations of violent, socially isolated male players (Kingsepp, 2006). As yet, little research supports this assumption (Happ \& Melzer, 2014) and in that regard contemporary concerns about video game culture reflect discussions during the first decades of film and television culture when social elites repeatedly railed against the corrupting influences of movies and TV on the multitudes of morally defenseless city folk. Sooner or later, however, most segments of society came to appreciate film, while historians kept their distance and even crafted a professional habitus in distinction to popular film and television culture (Tyrell, 2005: 75-80). The unusual staying power of the historians' prejudices toward visual media attests to the historians' ability to reproduce their professional practices and identities over time. At the same time, the persistence of prejudice indicates that historical film culture and historiography are indeed embroiled in a particularly intense relationship of competition and remediation. A significant segment of contemporary visual culture seems to constitute a fundamental provocation to the historians' sense of their professional mission.

\section{Film, Historiography, and Immersion}

The field of media studies offers excellent concepts to grasp the nature of this provocation. Historians appear to react particularly forcefully to the film dispositif's ability to trigger an experience of immersion and presence on the part of the movie audience. Immersion is defined as a degree of emotional and psychological involvement in a given media product that prompts media consumers to screen out other stimuli emanating from their environment, especially familiar stimuli of normal intensity. The state of immersion can lead to a veritable paradox. Given the right circumstances, viewers may temporar- 
ily perceive film experience as extra-filmic reality. Put differently, the sights and sounds of the film apparatus help generate a media-induced experience of non-mediation (Bolter \& Grusin, 1999; McMahon, 2003). The immersive conflation of representation and reality has historically occurred in all kinds of media settings (Wolf, Bernhart, \& Mahler, 2013). Immersion has also been an important element of reading cultures. But for most of the twentieth century the multi-sensory media of film and television have been particularly successful at drawing audiences into their narrative worlds. As a result, media consumers have frequently developed a sense of co-presence with objects and figures that populate these worlds. The sense of companionship with the figures on the screen can arise during the viewing process, is easily recognized as an emotional illusion after the show, but may surreptitiously return in powerful ways long after the screening has ceased because film and television, unlike historiography, play a decisive role in the construction of collective memories. Contemporaries all across the globe develop their individual and collective sense of self through participation in media routines. They imagine events of their own lifetime as well more distant history with the help of aggregate collages of personal experiences and mediated images and narratives (Garde-Hansen, 2011; Neiger, Meyers, \& Zandberg, 2011). It does not matter in this context that viewers might be perfectly able to distinguish between reality and representation-certainly when they are prompted on the spot to make that differentiation, for instance in the movie theater or on their living room couch. With hindsight, however, the constantly shifting perceptions of the past integrate all kinds of story elements without keeping track of the origin and epistemological status of the theme, mood, and subject matter under realignment. As a result, collective memories comprise dynamic composites of real life actors and fictitious and non-fictitious media figures creatively imagined within highly flexible standards of truth and authenticity and crafted in response to changing emotional needs and strategic goals. Film and television are structurally unsuitable for the reproduction of academic history but they offer superb platforms for the invention of social memory (cf. also Crane, 2012).

Incidentally, historians are very familiar with the experience of immersion but in professional history writing that experience takes place on the side of production not reception. There are plenty of academic historians who feel intimately related to their subject matter having spent a lifetime exploring one topic, era, or person from various angles and through extensive archival studies. They feel more at home in the past than the present. But their feelings of immersion derive from years of professionalization and research which might explain why many academics are so critical of the instantaneous immersive qualities of film and television. Academic history and media history are two radically different and incompatible ways of mimetically approaching the past and acquiring a sense of history as second nature. In historiography, immersion is an important tool of the trade and a key element of the professional ethos. Immersion into the past via authentic documents and official archives allows researchers to develop an empathetic relationship to past actors and events and 
attempt to grasp what really happened from the vantage point of the past not the present (e.g. Davis, 1987; Farge, 2015). Yet, in the aftermath of the often mythologized rite of passage in the archives, historian spent a great deal of time and effort to cast their archival encounters with the past into objectifying prose that systematically reduces rather than enhances the readership's opportunity for emotionally engaging with history. As intellectual processes, film history and academic history appear to unfold in opposite directions. In film and TV culture, a highly professionalized team of experts converts a basic story idea, often gleaned from academic writing, into a mimetically seductive and sensually and emotionally engaging simulation of the past fit for popular consumption. In contrast, historiographical culture transforms a highly subjective, often passionate, and lonesome encounter with remnants of the past into an intellectually overdetermined and emotionally underdetermined product adapted to the communication habits of a miniscule, highly specialized audience of peers. Film moves from intellectual reflection to immersion; academia from immersion to intellectual reflection. No wonder then that the two cultures have problems finding common ground despite their many points of contact (Schwarz, 2008; Treacey, 2016).

Teachers using film and television in the classroom are caught in the crossfire between academic and popular culture. Moreover and more important, if they are trying to teach students about professional historiography by way of exposure to historical film they commit a significant category mistake. It makes little sense to seek to explain the anti-immersive intellectual impetus of academic history by way of the hyper-immersive cultural codes of historical film. It is also not immediately obvious why a given group of students should be introduced to the highly idiosyncratic rituals and tastes of an academic culture with which they will likely never interact. But it makes a great deal of sense to reflect self-critically about the predilections and lacunae of past and present memory cultures by way of analyzing film and other visual narratives, especially if one confronts students with competing visions of the same topic or set of events. Film is particularly useful for memory education because the heyday of cinema culture has passed. For today's students film is an outdated communication technology, both alienating and sufficiently intriguing to extract them temporarily from their social media environments and involve them in a dialogue about visual literacy, cultural immersion, and the ethics of their collective memories.

\section{Public History}

The field of public history, which has risen to prominence in recent years and should provide guidance in this matter, is not much help either. In principle, public historians agree that visual culture has been the dominant cultural platform for modern societies' encounter with the past. As public historian Faye Sayer phrased it in 2015: "Television has become the closest most people will get, or even want to get, to experiencing history" (Sayer, 2015: 166). Sayer's 
words are revealing because they attest to an ambivalent attitude toward film and TV in the ranks of public historians dedicated to the cause of popular history education and adept at highlighting the disconcerting communication barriers between academic history and secondary school teaching environments. The Public History Reader published in 2013, which gives shape and purpose to the field, displays similar preferences and misgivings (Kean \& Martin, 2013; see also Ashton and Kean, 2012). Kean and Martin present public history as an attractive intellectual terrain. They elegantly anchor the field in its own distinct site of memory: Ruskin College in Oxford, an institution with a long track record of offering second chances to educationally disadvantaged adults and the former academic home of public history founding father Raphael Samuel. In addition to identifying an appropriate site of memory, the editors of the Public History Reader provide the field with a similarly compelling narrative identity. In a vivid and programmatic vignette, Kean and Martin invoke the display of live rats at the heritage site of the Hyde Park Barracks in Sydney, Australia as a particularly suitable strategy of engaging visitors with public history. The rats impress upon the visitors the tough conditions under which convicts and inmates survived in Sydney. The rats are acknowledged as pests but not vilified-quite the contrary. They are recognized as accidental public history archivists since the objects they stole from the immigrants and amassed in their hiding places have allowed twentieth-century historians to reconstruct the everyday lives of immigrants in much greater detail than would have been otherwise possible. In this way, the rats helped save people from oblivion who, in the universe of public history, are particularly deserving of historical attention. Moreover, the balanced assessment of the rats' role in history nicely illustrates another guiding principle of public history: the economically and symbolically downtrodden of this earth, (wo)men as well as beast, should be treated respectfully and not pitched against one another. Public history follows in the progressive footsteps of history from below and the history workshop movement and embodies a clear ethos demanding for the victims and underdogs of history the respect they deserve but rarely receive (Green, 2000). Finally, the field of public history appears committed to embracing strategies of historical immersion. After all, the rats of Hyde Park are an immersive exhibition strategy designed to put visitors in physical proximity of history.

But the situation is more complicated. Kean and Martin effectively link their project to prominent publications in the field thus defining public history as social form of knowledge grounded in contemporary life (Samuel, 1994) and concerned with illuminating the ways in which normal people engage with the past on a personal, group, and family level (De Groot, 2009). In this context, they also declare that "history is owned by those described in the narrative" (Kean \& Martin, 2013). Most likely, some professional historians would take issue with this statement and Kean and Martin thus inadvertently highlight an important fault line that repeatedly appears in their text. Public history as conceived of by Kean and Martin seems to have a conflicted relationship to academic history. On the one hand, academic historians are criticized for their 
insufficient appreciation of popular forms of historical knowledge. On the other hand, the field of public history subscribes to the methods of professional academic history including its principles of source criticism and its strategies of historical narration. As a result, public history displays some anxieties about its status as a professional discipline. Vigorous advocacy for non-professional appropriations of the past and respect for the discipline of history form an unstable intellectual mixture.

The ambivalence might explain why public history delineates an interesting middle ground with regard to historical immersion. Public historians seek to extend the immersive archival experience of historians to the public at large by extending and democratizing existing arenas of public engagement with the past. In public history, many environments count as archives. Public historians feel very comfortable facilitating encounters with history through memorials, museums, material culture, family history, oral history, and reenactments. But for many years they preferred to engage with tangible, physical acts of historical interpretation and face-to-face communication and kept their distance from the powerful simulative and immersive media of film, television, and video games. The ethos of public history thrived through active engagement with people and objects and public historian seemed to think, mistakenly I would argue, that TV consumers and game players are not actively crafting their own collective memories. The situation is changing now (Cauvin, 2016; Sayer, 2015) but as a result of the agreement between public historians and their colleagues in conventional history departments, film and electronic media have had few enthusiastic advocates within the discipline of history.

\section{From Why to How}

Those advocates are found in other departments, for instance in education departments. Education experts are less concerned about the integrity of the historical record and the status of the historical profession in public discourse. They appreciate visual media as excellent teaching tools and have a good grasp of what is really going on in a history classroom. In a refreshingly practiceoriented intervention published in 2010, education expert Alan Marcus and his colleagues celebrate film as "one of the most promising teaching resources in the history classroom" precisely because "young people today are immersed in visual representations" and most of what they know about the past "comes not from textbooks or teachers but from 'Hollywood' movies" (Marcus, Metzger, Paxton, \& Stoddard, 2010: loc 84). The authors dutifully acknowledge key historiographical concerns for instance regarding the differentiation between primary and secondary visual source material. But they also make perfectly clear that film and television are first and foremost exceptionally well suited to attain three important interrelated didactic goals which are not necessarily of primary concern to professional historians. First, visual media help students adopt caring attitudes toward minorities because "history movies can be particularly powerful ways to develop empathy, especially for groups of people who 
have been marginalized historically" (Marcus et al.: loc 240). Second, film and television are excellent tools for raising controversial topics, especially in the treacherous political terrain of primary and secondary schools in the USA. On the one hand, "social issues, group identities, and historical experiences that people often feel most passionate about are fundamental to the social studies curriculum" (loc 2017). On the other hand, addressing these controversial issues "can be messy, demanding, and risky for teachers" (loc 2027). Here film comes in handy because it is "particularly effective at evoking emotional responses" (loc 2351) while also providing some protection for teachers since they are not "the 'source' themselves" for potentially distressing opinions when they are showing films (loc 2414). In prompting students to develop and voice their own opinion about controversial issues, visual media are simply a fantastic vehicle to teach about contemporary memory politics. Finally, film and television can take on these important roles in the classroom because they can "bring the past alive" through visualization like no text can (Marcus \& Stoddard, 2007). Students get into close contact with an emotionally gripping performance of the past, might temporarily approximate the perspectives of past actors, and can develop a visceral appreciation of powerful past and present subject positions involved in the making and re-making of memory.

In their report from the classroom, replete with compelling teaching examples, Marcus et al. perform the shift from history to memory without engaging in defensive histrionics. They might not fully grasp and appropriately conceptualize that shift but their intervention acknowledges the fundamentally different notions of pastness that govern the writing and reading of academic history and the production and consumption of historical visual media. Academic history focuses on why-questions. Professional historians roam an ever-extending archival infrastructure and avidly read each other's work to determine the historical origins of constantly revised sets of events grouped into more or less abstract and flexible sets of overarching categories, for instance, war, genocide, democracy, modernity, gender, emotion and so on. In that dynamic environment with shifting intellectual priorities and resources, historians craft complex narrative artifacts interweaving various layers of historical events with accounts of different research agendas in order to determine the causes of more or less succinctly defined historical phenomena. Historical film and television serve a different purpose. There are many filmic products, especially documentaries dating back to the early decades of television, which duplicate professional historical culture and pursue why-questions, for instance by way of interviewing experts and historical eyewitnesses. These products are fairly boring and their existence is easily explained by the fact that the first generations of TV producers were unfamiliar with the medium of television and focused on intellectual concerns at their new work place that they had already pursued in their previous careers as print and radio journalists and academics. But once TV came into its own as a visual medium and assumed the role as premier social platform for cultural exchange in the 1960s and 1970s, history television increasingly engaged with a very different set of questions about past human lives that 
historical film had already addressed in compelling fashion for several decades. Film and television strive to teach viewers how the past felt like. Visual media mimetically perform past worlds in order to give their audiences a visceral feeling for the radical alterity or strange familiarity and present-day relevance of past lives (Edgerton \& Rollins, 2001; Kansteiner, 2013). What did it feel like to be an eyewitness to the Civil War, World War II, or the Holocaust? What does it feel like to be a victim, a bystander, or a perpetrator of war or genocide? The shift from why to how corresponds to the shift from history to memory and more specifically from academic history to film and television memory.

\section{Didactics of Modern Memory}

Until the rise of memory studies we did not have a clear conceptual framework for describing what films do with the past. For lack of imagination and conceptual alternatives we keep talking about film and history and historical film invoking at every step the world of academic scholarship. That intellectual habit does a serious disservice to both sides of the equation. With hindsight and the benefit of a memory studies vantage point (Erll, 2011; Olick, Vinitzky-Seroussi, \& Levy, 2011) it has become increasingly obvious that a non-visual, historically increasingly non-immersive and for many people unattractive technique for representing the past, which has not changed drastically since the times of Thukydides, has very little in common in terms of production and reception processes with mechanical/digital recording and editing devices that owe their tremendous success to their uncanny ability to perform the past as a type of instant replay. Consequently, memory studies not history is the appropriate academic framework for discussing filmic renditions of the past and, when using film and TV in the social studies classroom, we should be teaching about memory not about history in an academic sense (Guynn, 2006: 165-178).

Once we have accomplished the conceptual transition from history to memory, the extraordinary value of film and television as teaching tools becomes obvious. Film and TV mark an intriguing layer of media technology involved in intense remediation processes with both print culture and digital culture (Rippl, 2015). Film and TV are dynamic cultural environments and were the key media platforms shaping everyday lives across the globe for most of the twentieth century before they had to yield that role to digital media. The media events of film and television history have provided the rhythm of autobiographical memory and represent the cultural kernels around which generational, national, and transnational collective memories and identities have been constituted (Dayan \& Katz, 1992). Throughout the long and eventful century from the decade before WWI all the way to $9 / 11$, film and television established entertaining yet also relentless and highly centralized regimes of memory and forgetting sorting the visible and unforgettable from the invisible and negligible. Consequently, film and television represent humanity's memory of (post)modernity which we can better appreciate from the perspec- 
tive of 2017 since the political project of modernity and the analog media technologies of film and television appear clearly dated today. In fact, as long as we lacking sophisticated interactive digital games and platforms for the exploration of twentieth century history, film and television offer the only opportunity for immersively exploring modernity and its media landscape featuring film in a starring role as ( $\mathrm{l}$ ) an icon of modernity like the train, the car, and the factory; (2) the arena which shaped and distributed the dynamic culture of modernity and its iconography; (3) the communicative space which taught people how to be and act modern; (4) and, last but not least, the cultural resource permitting us to feel modernity intimately yet from a once removed vantage point (Kansteiner, 2015).

At the center of those remarkable 100 years of media history, inextricably intertwined with and neatly packaged by film and television culture, stand the key ethical challenges of the twentieth century: Nazism, Communism, and the Holocaust. The memories of these events will be shifting in the twenty-first century as they continue to transition from the realm of communicative memory to the realm of cultural memory. But at the moment, Holocaust memory is still the focus of Western transnational self-reflexive memory and well worth exploring (Fogu, Kansteiner, \& Presner, 2016). In fact, the key event of the history of post-WWII memory was the intense transnational encounter between the commercial Hollywood melodrama Holocaust and a (West) German national TV audience whose members learned for the first time on a large scale how to feel their way self-reflexively into the Nazi past and acquire a sense of empathy for the victims of the German crimes (Eder, 2016: 32-37). The media event Holocaust in Germany has been the gold standard of memory didactics for many decades. Ever since January 1979, film makers, television executives, and teachers of memory have strived to replicate that moment of self-reflexivity trying to match films, TV programs, and audiences in ways that help the latter acquire a critical perspective on their own collective accomplishments and shortcomings. The results have been mixed, fairly successful across Western Europe and less spectacular in the rest of the world. But the politics of regret are now a well-established tool of international politics and have led to an impressive track record of apologies and reparation agreements all across the world (Olick, 2007; Wolfe, 2014). Such developments would never have happened without years of successful memory didactics in the public sphere. Memory politics are always deployed strategically and in self-serving fashion but they also offer opportunities for empathetic unsettlement and self-reflexive learning primarily by way of exposure to visual historical culture.

\section{Layers of Film Memory}

Today's audiences are visual veterans who have seen it all. But even today's consumers can experience echoes of the powerful immersive experiences of past generations of moviegoers. Popular film culture began on the fair grounds and in vaudeville theaters of European capital cities of the 1890s. The cin- 
ema of attraction, as it has been called with hindsight, featured a wide variety of visual wonders, including technological marvels of industrialization, the unfamiliar flora, fauna, and indigenous cultures of Europe's far-flung empires, scenes of contemporary European everyday life with an emphasis on the surprising and grotesque, and short clips of fiction with little narrative depth (Gaudreault, 2011; Gunning, 1986). Audiences were enthralled with the new moving images. Contemporaries report about intense immersive incidents, for instance, of film spectators stampeding out of movie theaters when confronted head on with a moving train on the screen. That sense of panic could today only be (irresponsibly) induced in an extremely inexperienced, very young audience but faint repercussions of the original dread are still noticeable in the physical reactions of die-hard horror and fantasy fans as they choose to expose themselves to scenes of great brutality in rapid succession. When properly staged even the original train footage of 1895 might still induce a twitch of empathetic unsettlement in twenty-first century teenagers and that twitch makes all the difference for the didactics of collective memory. It contains an experiential flavor and the potential for emotional bonding and future remembrance which are difficult to convey through written reports about the spectators of the cinema of attraction. In this regard scholarly texts, textbook entries, and this very paragraph all share the same fate; they remain firmly grounded on the side of history not memory, represent rather than perform the past, and therefore fail to convey to consumers a tangible trace of what modern culture felt like when it was first invented. It takes exposure to images to explore self-reflexively how images have shaped our sense of self (Landsberg, 2004).

The experiences of the first consumers of the cinema of attractions offer a particularly vivid illustration of the potential of the didactics of memory although in principle all layers of film and television history can be deployed for these ends. That applies first and foremost to the invention of the Hollywood paradigm in the 1920s which has shaped codes and rituals of visual narration for almost a century (Gaines, 1992). Hollywood has elicited very different intellectual responses over the decades. For many film critics of the 1970s who adopted a Marxist point of view Hollywood fostered rather than critically engaged with the fundamental social contradictions of capitalist modernity (McCabe, 1974). Their one-dimensional assessment of Hollywood as a purveyor of false consciousness was fundamentally revised in the 1980s when a new generation of critics concluded that a productive tension between critical and instrumental reason was inscribed into the technical apparatus film. Consequently, they appreciated Hollywood as a complex, contradictory cultural institution shaped by forces of commerce and enlightenment (Bordwell et al., 1985). The progressive effects of Hollywood cinema stand out more clearly if one focuses on questions of reception. Only few Hollywood productions boast decidedly self-reflexive implied audiences but many mainstream feature films have nevertheless been implicated in critical social practices. Due to its complex visual language and global commercial reach, Hollywood helped underprivileged groups like women, migrants, and workers develop non-hege- 
monic transnational identities. In this way, blockbusters have had all kinds of social consequences including spawning alternative public spheres (Hansen, 1991). The cultural behemoth Hollywood has clearly never been a monolithic site of memory. It can be sliced and formed into all kinds of vectors, layers, and genre formations, especially with hindsight. Consider for instance the concept of film noir as one of many strategies of making sense of film history. Crafted after the fact in the 1970s for a series of highly stylized Hollywood crimedramas of the 1940s and 1950s, the concept and the films ooze mourning and nostalgia. The bewildering narrative worlds of film noir visually reflect and condense an era of rapid technological innovations during the war years, postwar consumerism, and the processes of social fragmentation climaxing in the 1960s. For the historically minded viewer, the performance of chronosophical oscillation in film noir also attests to a profound sense of sadness about the unfulfilled political promises of Western modernity (Dimendberg, 2004).

In addition to the cinema of attraction and Hollywood, the field of cinema studies offers other useful frames of interpretation and remembrance. Film historians and theorists have paid a lot of attention to experimental film, both the classical Avant-garde of the 1920s and their post-1960s successors (Turvey, 2011). Experimental films undercut the narrative and perspectival conventions of popular cinema and thus constitute a visual counter-memory of Western modernity (Landy, 2015). Similar motives of resistance are attributed to the critically acclaimed yet often popularly ignored European tradition of auteur filmmaking which flourished from the 1940s to the 1970s in Italian NeoRealism, the French New Wave, and New German Cinema. For the enthused critics, sound film modernists like Rossellini, Bergman, Truffaut, and Kluge managed to develop decelerated visual semantics which capture subjective psychological states of mind and experiences of time in ways that had previously simply not existed in visual media (Deleuze, 1992; De Baecque, 2011). The filmmakers used their unusual degree of cultural autonomy courtesy of the European welfare states to cast intellectual perceptions of life in post-fascist Europe into sensuous and self-reflexive film languages.

Tapping into cinema studies as a conceptual resource for teaching memory illustrates that didactics of film memory require engaging, presentist frames of interpretation. Teachers and students can only partake in self-reflexive memory practices if the visions of the past introduced in the classroom touch their selves in meaningful ways. But a presentist focus does not preclude theoretical deliberation. Quite the contrary. It makes perfect sense to use film theory to mold and lift to consciousness frames of remembrance (Halbwachs, 1992) which are grounded in contemporary social and cultural practices. In that way, academic cinema studies can play a constructive role in the didactics of visual memory and become part of a creative communicative setting involving teachers, students, and films of memory in sensual explorations of the past. Obviously, not all theoretical tools of cinema studies are equally suited for the task at hand. Marxist film theory of the 1970s, for example, would need a serious face-lift before it could serve as an appropriate sounding board 
for today's didactics of memory. Other theoretical concepts, for instance the post-colonial turn in visual studies, especially in conjunction with postcolonial educational practices (Andreotti, 2011), appear ideally suited for the creation of self-reflexive memory cultures in the West where many countries are struggling with long traditions of racism in conjunction with large-scale migration.

Post-colonial perspectives on film had a tough time taking hold in Western academia. Non-Western filmmakers had already in the 1960s identified their work as belonging to a Third Cinema in provocative distinction to the First Cinema, i.e. Hollywood, and the Second Cinema, i.e. the post-war European auteur film tradition Gabriel, 1995). But a post-colonial perspective was only gradually integrated into the cinema studies canon in the 1990s-with important intellectual consequences. In addition to confirming that film had played a decisive role in maintaining European colonial empires at home and abroad, the post-colonial turn firmly established non-Western traditions and actors in the history of film and called into question many of the traditional, Westerncentric narrative trajectories of cinema studies (Ponzanesi \& Waller, 2012). In essence, film was rescued from the nostalgic intellectual space demarcated by the engagement with early cinema, Hollywood, experimental film, and European auteur cinema and reestablished as a vibrant cultural platform for the discussion of key contemporary global challenges.

As a result of this recalibration of the history of cinema, the medium of film can now be much better deployed as a didactic tool for crafting progressive memory strategies in response to pressing global problems like pollution and migration. Both challenges are fraught with collective memory problems. When it comes to the movements of people around the globe, Western societies systematically misremember past migrations with dire consequences for today's political decision-making processes. Some movements of people are deemed troublesome and challenging. They are remembered as "migrations" and cast in racist visual stereotypes as for example the movements of so-called "guestworkers" in Europe since the 1950s and of war refugees today. Other movements of people might have constituted severe challenges when they occurred but are (mis)remembered as "homecomings," "expulsions," or "liberations," as for instance the large-scale population transfers in the immediate post-war years. The different registers for the memory of people on the move allow contemporary Western societies to cast self-images of settled stability against perceptions of alien threats. Western societies need new memories of themselves as people on the move receiving other people with similar experiences, desires, and objectives (Glynn \& Kleist, 2012).

While film and prime-time TV play a decisive role in reproducing dangerous stereotypes, they also offer excellent opportunities for crafting and deploying new collective symbols and self-reflexive memories. Consider in this context the topic of global pollution which has been subject to repeated waves of forgetfulness since it first garnered sustained international media coverage in the 1970s. Today, the topic attracts a lot of global attention in digital media which, 
in a process of remediation, might help penetrate existing layers of amnesia and passivity. Consider in this context the 2015 media event Under the Dome, a documentary about environmental pollution in China that attracted 300 million viewers within one week before its online distribution site was shut down by Chinese authorities. Clearly, future didactics of visual memory have to be concerned with a wide range of topics in addition to classic themes such as war and genocide.

\section{Celebrities and an Upcoming Funeral?}

In 2009 the publishers of Variety Magazine assembled an impressive line-up of 120 US celebrities reporting about "the movie that changed my life." The celebrities were grouped in interesting categories for instance "the romantics," featuring among others Reese Witherspoon and Hugh Hefner, "the dreammakers," including Nicole Kidman and Jack Nicholson, and "the bloodhounds" showcasing for instance James Patterson and Michael Connelly (Hofler, 2009). The book included a section for "the historians" presenting the movie picks of such luminaries as Tom Brokaw, Gore Vidal, and Doris Kearns Goodwin but failing to consider the movie reminiscences of any real life, bona fide academic historians. The Movie that Changed My Life thus inadvertently attests to the limited prestige and star power potential of the historical profession while purposefully highlighting the exceptional importance of visual media for autobiographical and collective memory.

For some people, books can also play a crucial role in their lives. There are numerous publications dedicated to the theme "the book that changed my life" although they primarily seem to serve the purposes of giving writers a chance to talk about their favorite reading experiences or affording devote Christians an opportunity for Bible exegesis (e.g. Coady \& Johannessen, 2007). In the meantime, we are still waiting for the Cambridge University Press compilation bestsellers The Dissertation that Changed My Life, The Scholarly Article that Changed My Life, and, especially eagerly awaited, The Textbook that Changed My Life. Until the emergence of an unlikely cultural setting in which history monographs, scholarly articles, and textbooks elicit the same kind of passions as films and fiction, and as long as we want people to care passionately about the past, we need to communicate to general audiences by way of immersive visual culture. The formerly widely successful formats of the prime-time documentary and the general release feature film are already anachronisms in this regard. Consumers will increasingly roam, remember, and care about the past as a result of their immersive and potentially counter-factual video game experiences (Kappell \& Elliott, 2013). I suspect for instance that there is now a generation at the game consoles that will primarily remember Karl Marx as a controversial, pathetic, and killable figure in the 2015 Assassins' Creed: Syndicate video game which is set in the expansive and impressively interactive history-scape of Victorian London. 


\section{REFERENCES}

Andreotti, V. (2011). Actionable Postcolonial Theory in Education. New York: Palgrave Macmillan.

Ashton, P., \& Kean, H. (Eds.). (2012). Public History and Heritage Today: Peoples and Their Past. Basingstoke: Palgrave Macmillan.

Beard, C. (1934). Why Get It Wrong? Sight \& Sound, 2(8), 124.

Bolter, J. D., \& Grusin, R. (1999). Remediation. Understanding New Media. Cambridge, MA: MIT Press.

Bordwell, D., et al. (1985). The Classical Hollywood Cinema: Film Style and Mode of Production to 1960. London: Routledge \& Kegan Paul.

Burnett, E. (Ed.). (2008). History through Film, Vol. 1. Raleigh: Lulu Press.

Carnes, M. (1996). Past Imperfect. History According to the Movies. New York: Henry Holt and Company.

Cauvin, T. (2016). Public History. A Textbook of Practice. New York: Routledge.

Chapman, J. (2013). Film and History. Basingstoke: Palgrave Macmillan.

Coady, R., \& Johannessen, J. (Eds.). (2007). The Book That Changed My Life: 71 Remarkable Writers Celebrate the Books that Matter Most to Them. New York: Penguin.

Crane, S. (2012). Seeing the Past 1800-1900-2000. History as a Photo Album. In B. Korte \& S. Paletschek (Eds.), Popular History Now and Then. International Perspectives (pp. 263-280). Bielefeld: Transcript.

Custen, G. (1992). Bio/Pics. How Hollywood Constructed Public History. New Brunswick: Rutgers University Press.

Davis, N. Z. (1987). Fiction in the Archives. Stanford: Stanford University Press.

Dayan, D., \& Katz, E. (1992). Media Events: The Live Broadcasting of History. Cambridge, MA: Harvard University Press.

De Baecque, A. (2011). Camera Historica: The Century in Cinema. New York: Columbia University Press.

De Groot, J. (2009). Consuming History: Historians and Heritage in Contemporary Culture. London: Routledge.

Deleuze, G. (1992). Cinema, Vol. 1: The Movement Image. Minneapolis: University of Minnesota Press.

Dimendberg, E. (2004). Film Noir and the Spaces of Modernity. Cambridge, MA: Harvard University Press.

Eder, J. (2016). Holocaust Angst. The Federal Republic of Germany and American Holocaust Memory since the 1970s. Oxford: Oxford University Press.

Edgerton, G., \& Rollins, P. (Eds.). (2001). Television Histories. Shaping Collective Memory in the Media Age. Lexington: The University Press of Kentucky.

Erll, A. (2011). Memory in Culture. New York: Palgrave Macmillan.

Farge, A. (2015). The Allure of the Archives. Yale: Yale University Press.

Ferro, M. (1988). Cinema and History. Detroit: Wayne State University Press.

Fogu, C., Kansteiner, W., \& Presner, T. (Eds.). (2016). Probing the Ethics of Holocaust Culture. Cambridge, MA: Harvard University Press.

Gabriel, T. (1995). Towards a Critical Theory of Third World Films. In M. Martin (Ed.), Cinemas of the Black Diaspora. Diversity, Dependence, and Oppositionality (pp. 70-90). Detroit: Wayne State University Press.

Gaines, J. (1992). Classical Hollywood Narratives: The Paradigm Wars. Durham: Duke University Press. 
Garde-Hansen, J. (2011). Media and Memory. Edinburgh: Edinburgh University Press. Gaudreault, A. (2011). Film and Attraction: From Cinematography to Cinema. UrbanaChampaign: University of Illinois Press.

Glynn, I., \& Kleist, O. (2012). History, Memory and Migration. Perceptions of the Past and the Politics of Incoporation. New York: Palgrave Macmillan.

Grainge, P. (Ed.). (2003). Memory and Popular Film. Manchester: Manchester University Press.

Green, J. (2000). Taking History to Heart. The Power of the Past in Building Social Movements. Amherst: University of Massachusetts Press.

Gunning, T. (1986). The Cinema of Attraction: Early Film, Its Spectator and the AvantGarde. Wide Angle, 8, 1-14.

Guynn, W. (2006). Writing History in Film. New York: Routledge.

Halbwachs, M. (1992). On Collective Memory. Chicago: University of Chicago Press.

Hansen, M. (1991). Babel and Babylon: Spectatorship in American Silent Film. Cambridge, MA: Cambridge University Press.

Happ, C., \& Melzer, A. (2014). Empathy and Violent Video Games: Aggression and Prosocial Behavior. Basingstoke: Palgrave Macmillan.

Hofler, R. (Ed.). (2009). Variety's “The Movie that Changed My Life:” 120 Celebrities Pick the Films That Made a Difference. Philadelphia: Da Capo Press.

Hughes-Warrington, M. (2009). Introduction: History on Film: Theory, Production, Reception. In M. Hughes-Warrington (Ed.), The History on Film Reader (pp. 1-12). New York: Routledge.

Kansteiner, W. (2013). Macht, Authentizität und die Verlockungen der Normalität. Aufstieg und Abschied der NS-Zeitzeugen in den Geschichtsdikumentationen des ZDF. In M. Sabrow \& N. Frei (Eds.), Die Geburt des Zeitzengen nach 1945 (pp. 320-353). Göttingen: Wallstein.

Kansteiner, W. (2015). Filmwissenschaft. In F. Jaeger, W. Knöbl, \& U. Schneider (Eds.), Handbuch Moderneforschung (pp. 81-93). Stuttgart: Metzler.

Kappell, M., \& Elliott, A. (Eds.). (2013). Playing with the Past. Digital Games and the Simulation of History. London: Bloomsbury.

Kean, H., \& Martin, P. (Eds.). (2013). The Public History Reader. London: Routledge. Kingsepp, E. (2006). Immersive Historicity in World War II Digital Games. Human IT, 8 nr. 2, 60-89.

Kracauer, S. (1969). History: The Last Things Before the Last. New York: Oxford University Press.

Landsberg, A. (2004). Prosthetic Memory. The Transformation of American Remembrance in the Age of Mass Culture. New York: Columbia University Press.

Landy, M. (2015). Cinema and Counter-History. Bloomington: Indiana University Press.

Marcus, A., \& Levine, T. (2007). Exploring the Past with Feature Film. In A. Marcus (Ed.), Celluloid Blackboard: Teaching History with Film (pp. 1-13). Charlotte, NC: IAP.

Marcus, A., \& Stoddard, J. (2007). Tinsel Town as Teacher: Hollywood Film in the High School History Classroom. The History Teacher, 40(3), 303-330.

Marcus, A., Metzger, S., Paxton, R., \& Stoddard, J. (2010). Teaching History with Film: Strategies for Secondary Social Studies. New York: Routledge.

McCabe, C. (1974). Realism and the Cinema: Notes on Some Brechtian Theses. Screen, 15(2), 7-27. 
McMahon, A. (2003). Immersion, Engagement, Presence: A Method for Analyzing 3-D Video Games. In M. Wolf \& B. Perron (Eds.), The Video Game Reader (pp. 67-86). New York: Routledge.

Monk, C. (2011). Heritage Film Audiences: Period Films and Contemporary Audiences in the UK. Edinburgh: Edinburgh University Press.

Neiger, M., Meyers, O., \& Zandberg, E. (Eds.). (2011). On Media Memory. Collective Memory in a New Media Age. New York: Palgrave Macmillan.

O'Connor, J. (1987). Teaching History with Film and Television. Washington: American Historical Association.

Olick, J. (2007). The Politics of Regret. On Collective Memory and Historical Responsibility. New York: Routledge.

Olick, J., Vinitzky-Seroussi, V., \& Levy, D. (Eds.). (2011). The Collective Memory Reader. Oxford: Oxford University Press.

Ponzanesi, S., \& Waller, M. (Eds.). (2012). Postcolonial Cinema Studies. London: Routledge.

Ramirez, B. (2014). Inside the Historical Film. Quebec: McGill-Queen's Press.

Rippl, G. (Ed.). (2015). Handbook of Intermediality. Literature-Image-SoundMusic. Berlin: De Gruyter.

Rosenstone, R. (1992). [Introduction Film Reviews]. The American Historical Review, 97(4), 1138-1141.

Rosenstone, R. (1995a). Visions of the Past: The Challenge of Film to Our Idea of History. Cambridge, MA: Harvard University Press.

Rosenstone, R. (Ed.). (1995b). Revisioning History: Film and the Construction of a New Past. Princeton: Princeton University Press.

Rosenstone, R. (2006). History on Film: Film on History. Harlow: Pearson Longman.

Ross, S. (1999). Working Class Hollywood: Silent Film and the Shaping of Class in America. Princeton: Princeton University Press.

Samuel, R. (1994). Theatres of Memory: Past and Present in Contemporary Culture. London: Verso.

Sayer, F. (2015). Public History: A Practical Guide. London: Bloomsbury.

Schneider, R. (2006, May). On Film Reviews in the AHR. Perspectives.

Schwarz, V. (2008). Film and History. In J. Donald \& M. Renov (Eds.), The Sage Handbook of Film Studies (pp. 199-215). London: Sage.

Shandler, J. (1999). While America Watches. Televising the Holocaust. New York: Oxford University Press.

Short, K. (Ed.). (1981). Feature Films as History. London: Croom Helm.

Smith, P. (Ed.). (1976). The Historian and Film. Cambridge, UK: Cambridge University Press.

Smyth, J. E. (2012). Introduction. In J. E. Smyth (Ed.), Hollywood and the American Historical Film (pp. xvi-xxv). New York: Palgrave Macmillan.

Sorlin, P. (1980). The Film in History: Restaging the Past. Oxford: Basil Blackwell.

Stubbs, J. (2014). Historical Film: A Critical Introduction. New York: Bloomsbury.

Treacey, M. (2016). Reframing the Past: History, Film and Television. New York: Routledge.

Turvey, M. (2011). The Filming of Modern Life: European Avant-Garde Film of the 1920s. Cambridge, MA: MIT Press.

Tyrell, I. (2005). Historians in the Public. The Practice of American History, 1890-1970. London: University of Chicago Press. 
Witthöft, H. (1970). Zeitgeschichtliche Filmdokumente im Geschichtsunterricht. In G. Moltmann \& K.-F. Reimers (Eds.), Zeitgeschichte im Film- und Tondokument [Contemporary History in Film and Sound Document] (pp. 217-225). Göttingen: Musterschmidt.

Wolf, W., Bernhart, W., \& Mahler, A. (Eds.). (2013). Immersion and Distance: Aesthetic Illusion in Literature and Other Media. Amsterdam: Rodopi.

Wolfe, S. (2014). The Politics of Reparations and Apologies. New York: Springer. 